\title{
FENOMENA-FENOMENA DI SEPUTAR KEBIJAKAN INITIAL PUBLIC OFFERING (IPO) DAN PENGUKURAN KINERJA PERUSAHAAN DI INDONESIA
}

\author{
Agus Sucipto \\ Fakultas Ekonomi Universitas Islam Negeri (UIN) Malang \\ J1. Gajayana No. 50, Telepon (0341) 558881, Fax. (0341) 558881, \\ E-mail: feuinmlg@yahoo.co.id
}

\begin{abstract}
Abtract
Usually, the firm will go public start it by initial public offering (IPO) at primary market. So, it is sold at secondary market. Something is no needed by emitent, that is occurred too high underpricing, that is situation where share price at the first day at secondary market higher than primary market. Underpricing is interesting phenomenon, because a large part of market security in the world is experience. Other phenomenon accompany IPO is asymmetric information. Although investors have enough information about the IPO's firm, asymmetric information remains will be happened. This situation motivate management to manipulate his performance both before and the moment of IPO. This manipulation is known earnings management that resulted underperformance after IPO. Nevertheless, the other side, earnings management will influence value of the firm. This condition is happened cause of earnings is published at the moment of IPO relatively better so market's response is good. The policy of earnings management is addressed to give positive signal to market about the firm. It appear at the statement of performance (usually at the IPO's prospectus). However, at the long time, this positive signal can't be maintained by management, it is reflected at decreasing performace published by the firm.
\end{abstract}

Key word: initial pblic offering (IPO), primary market, secondary market, earnings management, asymmetric information, underpricing

Kebutuhan dana bagi perusahaan dapat dipenuhi dari modal sendiri, hutang dari bank, pengeluaran surat hutang, ataupun juga mengeluarkan saham. Dimana pada setiap bentuk sumber pendanaan tersebut terdapat kelebihan dan kelemahan masing-masing. Perusahaan yang memperoleh sumber pendanaan dari saham menunjukkan bahwa perusahaan akan berubah dari perusahaan pribadi menjadi perusahaan publik atau lebih dikenal dengan go public. Perubahan perusahan menjadi perusahaan publik merupakan perubahan fundamental dalam gaya hidup perusahaan tersebut. Perusahaan yang akan go public biasanya dimulai dengan keputusan melakukan initial public offerings (IPO) yang dilakukan di pasar perdana (primary market). Selanjutnya saham tersebut akan di perjual-belikan di pasar modal atau disebut pasar sekunder (secondary market).

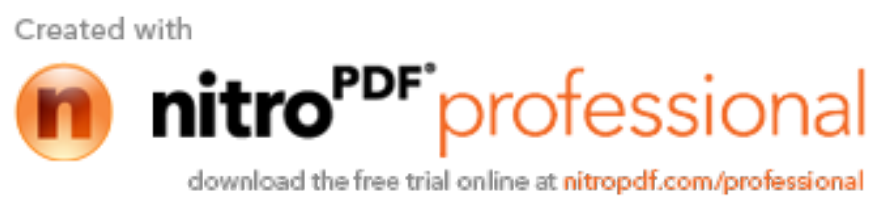


Harga saham pada penawaran perdana ditentukan berdasarkan kesepakatan antara perusahaan emiten dengan penjamin emisi efek (underwriter) sebagai pihak yang membutuhkan dana, emiten menginginkan harga perdana tinggi. Sebaliknya, underwriter sebagai penjamin emisi berusaha untuk meminimalkan risiko yang ditanggungnya. Dalam tipe penjaminan full comitment, pihak underwriter akan membeli saham yang tidak di jual di pasar perdana. Keadaan tersebut membuat underwriter tidak berkeinginan untuk membeli saham yang tidak laku dijual. Upaya yang dilakukan adalah dengan bernegosiasi dengan emiten agar saham tersebut tidak terlalu tinggi harganya, bahkan cenderung underpriced.

Salah satu hal yang tidak diinginkan oleh pihak emiten dalam hal ini perusahaan yang melakukan IPO adalah terjadi underpricing yang terlalu tinggi, yaitu keadaan dimana harga saham hari pertama di pasar sekunder (bursa) lebih besar dari pada harga saham perdananya. Apabila terjadi keadaan tersebut maka perusahaan gagal memperoleh dana yang maksimum dari pelaksanaan IPO, sehingga dalam penentuan harga saham perdana emiten sangat berkepentingan untuk menetapkan harga yang maksimum untuk harga saham perdana dari perusahaannya. Di sisi lain harga perdana yang underpriced akan memberikan initial return yang positif bagi investor ketika saham tersebut mulai diperdagangkan di pasar modal.

Underpricing merupakan fenomena yang menarik karena dialami oleh sebagian besar pasar modal di dunia. Karena itu seringkali pada pasar perdana (IPO) dijumpai fenomena underpricing (Ritter, 1984; Ritter,1991; McGuinnes, 1992; Husnan, 1993; Aggrawal, et al., 1993; Kunz and Aggrawal, 1994; Hanafi, 1997; Ernyan dan Husnan, 2002). Penelitian yang dilakukan oleh Aggrawal, et al. (1993) menyimpulkan bahwa IPO dalam jangka pendek menunjukkan terjadinya underpricing, tetapi dalam jangka panjang terjadi return yang negatif. Underpricing ini di satu pihak menguntungkan investor tetapi di pihak lain akan merugikan emiten karena dana yang dikumpulkan tidak maksimal. Penurunan kinerja yang terjadi dalam jangka panjang akan merugikan investor karena akan memperoleh return yang negatif. Menurut Ritter (1991) faktor yang bisa menjelaskan terjadinya penurunan kinerja (underperformance) tersebut adalah kesalahan dalam pengukuran risiko, bad luck, dan terlalu optimisnya investor terhadap prospek perusahaan.

Fenomena lain menunjukkan adanya asimetri informasi (asymmetric information) yang menyertai kebijakan IPO. Walaupun investor mempunyai informasi yang cukup mengenai perusahaan yang melakukan IPO tersebut, asimetri informasi tetap terjadi dalam penawaran ini 
(Ritter, 1986; Beatty, 1989; Leland dan Pyle, 1997; Guo dan Mech, 2000). Kondisi inilah yang memotivasi manajemen untuk bersikap oportunistik untuk melakukan manipulasi terhadap kinerjanya baik sebelum dan pada saat penawaran (Jones, 1991; Friedlan, 1994; Gumanti, 2001; Setiawati, 2002; Ihalauw dan Afni, 2002). Manipulasi yang dikenal dengan istilah earnings management (manajemen laba) ini akan mengakibatkan penurunan kinerja (underperformance) setelah penawaran (Ritter, 1991; Carter et al., 1998). Namun praktek earnings management di sisi lain dapat mempengaruhi nilai perusahaan (Mayangsari dan Wilopo, 2001). Kondisi ini terjadi karena earnings yang diumumkan pada saat IPO tampak relatif baik sehingga respon pasar menjadi positif. Paek dan Press (1997) dalam Wilopo dan Mayangsari (2002) menyatakan bahwa nilai pasar perusahaan dipengaruhi oleh motivasi manajer yang mendasari adanya discretionary accruals dalam kebijakan earnings management.

Kebijakan earnings management dalam hal ini ditujukan untuk memberikan sinyal positif kepada pasar tentang perusahaan yang dikelolanya. Sinyal positif ini diwujudkan dalam kinerja yang dilaporkan (biasanya dalam prospektus penawaran). Namun sinyal positif ini dalam jangka panjang tidak bisa dipertahankan oleh manajemen, yang tercermin dari penurunan kinerja yang dilaporkan oleh perusahaan tersebut (Teoh et al., 1998). Loughran dan Retter (1997) menemukan perbedaan antara kinerja operasi lima tahun sebelum dan sesudah penawaran, yaitu adanya penurunan kinerja dalam jangka panjang. Rodoni (2002) juga menemukan bahwa kinerja IPO untuk jangka panjang menunjukkan kinerja yang negatif.

Sementara Denis dan Serin (1999) mencatat bahwa rendahnya kinerja pasca IPO diakibatkan pengukuran earnings yang dilakukan secara "tidak tepat" oleh manajemen. Kondisi ini mempengaruhi interpretasi investor terhadap kinerja perusahaan dan mengakibatkan investor mempunyai harapan profitabilitas masa depan perusahaan yang keliru. Atau dengan kata lain investor yang naif akan over-optimistik dalam maramalkan earnings masa depan dan mengalami kekecewaan terhadap realisasinya pada periode pasca penawaran. Penurunan kinerja yang terjadi sebagai dampak pengukuran tersebut akan terjadi selama lima tahun setelah IPO. Shivakumar (2000) juga menunjukkan bahwa manajemen telah melakukan overstate terhadap earnings sebelum malakukan pengumuman IPO. Lebih lanjut penelitian tersebut menunjukkan bahwa investor sebenarnya sudah menduga adanya manajemen laba (earnings management) dan secara rasional berusaha melepaskan pengaruhnya pada saat 
pengumuman IPO. Jadi investor memiliki penilaian yang rendah terhadap earnings sebelum IPO dan secara rasional memberikan nilai yang rendah untuk perusahaan.

Di Indonesia penelitian mengenai fenomena underpricing, earnings management, dan penurunan kinerja yang terjadi setelah IPO masing-masing dilakukan oleh Husnan (1996); Hanafi (1997); Gumanti, 2001; Setiawati, 2002; Ihalauw dan Afni, 2002); Nasirwan (2000), Pratiwi dan Kusuma (2001); Harto (2001); Candy (2002); Rodoni (2002). Fenomena underpricing ditemukan oleh Husnan (1996) dan Hanafi (1997), bahwa IPO pada perusahaan-perusahaan privat maupun perusahaan milik negara (BUMN) biasanya mengalami underpriced. Sementara Gumanti, 2001; Setiawati, 2002; Ihalauw dan Afni, 2002) menemukan bukti bahwa sebelum dan sesudah IPO perusahaan melakukan kebijakan earnings management. Nasirwan (2000) menunjukkan bahwa kinerja perusahaan mengalami penurunan, tetapi penurunannya relatif kurang begitu tajam untuk saham perusahaan yang dikelola penjamin emisi yang mempunyai reputasi lebih tinggi. Pratiwi dan Kusuma (2001), menemukan bahwa kinerja IPO jangka pendek (tiga bulan) adalah positif $(39,67 \%)$ dan kinerja jangka panjang (dua puluh empat bulan) adalah negatif $(-238,83 \%)$. Bukti ini menunjukkan bahwa dalam jangka panjang telah terjadi penurunan kinerja (underperformance). Harto (2001) dan Rodoni (2002) menyimpulkan bahwa perusahaan yang melakukan IPO mengalami penurunan kinerja operasi, keuangan, dan saham selama tiga tahun setelah penawaran. Sedangkan Candy (2002) dalam penelitian mengenai IPO menyimpulkan bahwa perusahaan akan mengalami penurunan kinerja operasi, sedangkan kinerja keungan justru mengalami kenaikan.

Beberapa penelitian sebelumnya telah menguji fenomena underpricing pada saat IPO dan menguji fenomena earnings management yang menyertai kebijakan IPO serta menguji kinerja saham pasca IPO, namun tidak menguji fenomena-fenomena tersebut secara komprehensif (serempak). Padahal ketiga fenomena tersebut merupakan fenomena yang selalu menyertai pelaksanaan IPO. Berawal dari adanya asimetri informasi yang mendorong sikap oportunistik manajer untuk melakukan manipulasi terhadap kinerjanya sebelum penawaran (yang tercermin dalam prospektus perusahaan). Manipulasi yang dilakukan manajer dapat menjadi IPO-trap (jebakan IPO) bagi investor. Manajemen melakukan manipulasi dengan menggunakan discretionary accruals, yaitu kebijakan akuntansi yang memberikan keleluasaan pada manajemen untuk menentukan jumlah transaksi akrual secara fleksibel. Sehingga terjadi peningkatan laba (income increasing) menjelang penawaran (IPO), memuncak pada saat penawaran dan menurun 
setelah penawaran dan dalam jangka panjang akan berdampak pada penurunan kinerja perusahaan. Sehubungan dengan itu, penelitian ini bermaksud mendeteksi adanya kebijakan earnings management yang menyertai IPO, fenomena underpricing saat IPO dan kinerja perusahaan pasca IPO secara bersama-sama.

\section{INITIAL PUBLIC OFFERINGS (IPO)}

Saham-saham perusahaan yang belum mempublik awalnya dimiliki oleh manajer, pegawai, dan hanya sebagian kecil dimiliki investor. Sebagaimana biasanya, jika perusahaan berkembang, kebutuhan modal tambahan sangat dirasakan. Pada saat ini perusahaan harus menentukan untuk menambah modal dengan cara utang atau menambah jumlah dari pemilik dengan menerbitkan saham baru. Jika saham akan dijual untuk menambah modal, maka saham baru dapat dijual dengan berbagai macam cara antara lain dengan menawarkan kepada publik (going public) (Hartono, 2000: 16).

Jika perusahaan memutuskan untuk menawarkan kepada publik dan melemparkan sahamnya ke publik (initial public offering), isu utama yang muncul adalah tipe saham yang akan dilempar, berapa harga saham yang harus ditetapkan untuk selembar sahamnya, dan kapan waktunya yang paling tepat. Umumnya perusahaan menyerahkan permasalahan yang berhubungan dengan IPO ke banker investasi yang mempunyai keahlian dalam penjualan sekuritas. Penjualan saham baru perusahaan yang melibatkan banker investasi ini dijual di pasar primer (primary market).

Banker merupakan perantara antara perusahaan yang menjual saham dengan investor. Sebagai perantara, banker investasi selain berfungsi sebagai pemberi saran (advisory function), juga berfungsi sebagai pembeli saham (underwriter function), dan berfungsi sebagai pemasar saham ke investor (marketing function) (Hartono, 2000: 18-19).

Proses pembelian sekuritas oleh banker investasi yang nantinya akan dijual kembali ke publik yang disebut dengan underwriting. Banker investasi yang melakukan underwriting ini disebut underwriter. Underwriter merupakan anggota pasar modal, yang di Bursa Efek Jakarta (BEJ) atau yang disebut dengan securities house. Banker investasi membeli sekuritas dengan harga yang disetujui dan menanggung risiko kegagalan atau kerugian menjual kembali ke publik dan banker investasi mengambil keuntungan dari selisih harga beli dan harga jual saham yang disebut spread ( Hartono, 2003: 19). 
Initial Publik Offering (IPO) merupakan penawaran saham perusahaan untuk pertama kalinya dan dilakukan di pasar primer. Selanjutnya saham tersebut akan diperjualbelikan di pasar bursa atau di pasar sekunder. Harga saham perdana ditentukan berdasarkan kesepakatan antara perusahaan emiten dengan underwriter (penjamin emisi efek) sebagai pihak yang membutuhkan dana, emiten menginginkan harga perdana tinggi. Sebaliknya, underwriter sebagai penjamin emisi berusaha untuk meminimalkan risiko yang ditanggungnya tipe penjamin full comitment, pihak underwriter akan membeli saham yang tidak dijual di pasar perdana. Keadaan tersebut akan membuat underwriter tidak berkeinginan untuk membeli saham yang tidak laku dijual. Upaya yang dilakukan adalah dengan bernegosiasi dengan emiten agar saham tersebut tidak terlalu tinggi harganya bahkan cenderung underpriced.

\section{Underpricing}

Underpriced adalah hasil dari ketidakpastian harga saham pada pasar sekunder (Carter dan Manaster, 1990). Underpricing adalah penentuan harga saham di pasar perdana lebih rendah daripada harga di pasar sekunder untuk saham yang sama. Harga perdana yang underpriced akan memberikan initial return yang positif bagi investor, dan saham tersebut mulai diperdagangkan di pasar bursa.

Underpricing merupakan fenomena yang menarik karena dialami oleh sebagian besar pasar modal di dunia. Di Indonesia fenomena tersebut di temukan oleh Husnan (1996) menunjukan bahwa IPO pada perusahaan-perusahaan privat maupun pada perusahaan milik negara (BUMN) biasanya mengalami underpriced.

Underpricing terjadi lebih tinggi karena lebih besar tingkat campur tangan pemerintah, permulaan dalam proses penawaran umum yang digunakan adalah harga penawaran yang tetap dan perusahaan yang melakukan penawaran umum berisiko lebih tinggi (Rodoni dan Yong, 2002:180). Dalam banyak kasus ditemukan bahwa harga saham perdana berada dibawah harga pasar (underpriced), sehingga investor tertarik untuk membeli saham pada pasar perdana untuk mendapatkan return pada saat berada di pasar sekunder. Underpriced adalah suatu kondisi dimana harga saham pada penawaran perdana lebih rendah daripada harga saham pada hari pertama perdagangan di pasar sekunder.

Loughran, et al.(1996), menjelaskan bahwa pemilik perusahaan secara rasional menjual saham kepada pihak luar dengan harga kurang daripada yang sepatutnya yaitu harga-harga 
maksimum yang dapat dicapai. Loughran, et al, (1994), bukti yang dapat menyebabkan underpricing adalah sebagai berikut:

a) Lebih besar campur tangan pemerintah.

b) Permulaan dalam peroses penawaran umum yang digunakan adalah harga penawaran yang tetap.

c) Perusahaan yang melakukan penawaran umum berisiko lebih tinggi.

Menurut Baron (1986) secara teori bahwa underpricing terjadi ketika penjamin emisi memperoleh informasi yang lebih baik dibandingkan dengan emiten dan mempunyai kontrol terhadap jumlah harga dan distribusi penerbitan baru kepada umum. Menurut Fock (1986) menyatakan bahwa underpricing adalah hasil dari pada asimetri informasi antara para investor, umumnya investor yang mempunyai informasi akan menyertai penerbitan saham baru berdasarkan kepada informasi yang lebih baik berkenaan dengan penerbitan saham perusahaan. Menurut Beatty dan Ritter (1986) menyatakan bahwa berkurangnya harga (underpricing) merupakan fungsi peningkatan ketidakpastian sebelumnya yang dialami oleh pasar yang dihubungkan dengan persetujuan penjamin emisi.

\section{Asymmetric Information}

Asimetri Informasi dalam kegiatan di pasar modal merupakan fenomena yang sering terjadi. Adanya Asimetri Informasi ini yang menyebabkan terjadinya underpricing pada harga IPO, meskipun untuk teori yang menyatakan penyebab dari adanya asimetri informasi itu sendiri masih kontroversi. Baron (1982), Leland dan Pyle (1997) menawarkan hipotesis asimetri informasi untuk menjelaskan perbedaan informasi yang dimiliki oleh pihak-pihak yang terlibat dalam penawaran perdana, yaitu emiten, underwriter, dan masyarakat pemodal. Underwriter memiliki informasi tentang pasar lebih lengkap daripada emiten, sedangkan terhadap calon investor, underwriter memiliki informasi lebih lengkap tentang kondisi emiten. Semakin besar informasi asimetri yang dihadapi oleh calon investor semakin besar pula mereka akan mempenalty penawaran harga di pasar perdana yang akan memaksa underwriter menawarkan saham tersebut dengan underpriced. Sedangkan Rock (1986) dalam Weston (1997:409) menyatakan bahwa penyebab terjadinya asimetri informasi adalah karena adanya kesenjangan informasi antara investor yang memiliki informasi dengan investor yang tidak memiliki informasi.

Investor yang memilki informasi akan membeli saham yang dianggap akan memberi return yang tinggi untuk di masa depan. Sedangkan untuk investor yang tidak memilki 
invormasi akan membeli saham tanpa mengetahui saham tersebut memberikan return yang tinggi atau tidak untuk dimasa depan. Dalam kondisi tersebut dimana investor yang tidak memiliki informasi akan mendapatkan kerugian yang besar karena adanya kesenjangan informasi tersebut, untuk itu agar setiap kelompok dari investor yang ada tidak terlalu diuntungkan atau terlalu dirugikan atau dengan kata lain agar setiap kelompok yang berpartisipasi mendapatkan return yang wajar, maka dikembangkan model winner's curse, dimana harga penawaran dibuat underpriced.

\section{Jujur dalam Transaksi dan Informasi}

Jujur merupakan keutamaan akhlaq Islami yang diperintahkan kepada seluruh umat Islam. Islam menekankan kepada kelompok pelaku bisnis dan memerintahkan mereka untuk berpegang teguh pada penjelasan dan keterangan terhadap apa yang mereka jual dan yang mereka beli. Jika jujur hukumnya wajib bagi berbagai transaksi bisnis kecil, maka kewajiban tersebut lebih kuat dan lebih ditekankan pada transaksi di bursa efek dimana bisa jadi memberikan keterangan bohong berakibat pada hancurnya pasar secara keseluruhan, atau bahkan hancurnya ekonomi Negara. Rasulullah saw. telah menjelaskan balasan atas kejujuran dan orang-orang yang jujur serta akibat yang bakal menimpa kebohongan dan orang-orang yang berbohong dalam lebih dari satu hadis. Rasulullah bersabda yang diriwayatkan oleh Hakim bin Hijamra, yang disepakati kesahihannya oleh Bukhari dan Muslim: “Dua orang yang berjual beli mempunyai hak pilih selama mereka berdua belum berpisah, jika mereka jujur dan saling menjelaskan mereka diberkahi dalam berjual beli mereka dan jika berbohong dan menyembunyikan (aib) maka barokah jual beli mereka dihapus."

Dari Abi Said Al-Khudri ra. Dari Nabi saw. bersabda "Pedagang yang jujur dan amanah bersama para nabi, orang-orang yang jujur dan para syuhada." (HR. At-Turmudzi)

Dari Abdurrahman bin Syibl ra. Berkata "Saya mendengar Rasulullah saw. bersabda: "sesunguhnya para pedagang adalah fujjar (ahli maksiat)". Para sahabat bertanya "Wahai Rasululah bukankah Allah telah menghalalkan jual beli?" Rasulullah bersabda: "Benar, tetapi ketika mereka bersumpah maka mereka melanggarnya dan ketika mereka berkata mereka berbohong." (HR. Ahmad dalam Musnadnya).

Jujur dalam bertransaksi bisnis menanamkan rasa kepercayaan (tsiqah) dalam diri dan menumbuhkan rasa ketenangan dalam ati setiap penjual dan pembeli dan menjadikan urusan mereka berdua menjadi jelas. Mereka menyempurnakan akad jual beli atau membatalkan 
semua menurut keinginan mereka bedua. Tidak diragukan lagi bahwa hal ini merupakan salah satu landasan bisnis yang paling tinggi dan menjauhkan pasar dari goncangan ekonomi yang dahsyat yang disebabkan oleh informasi yang menyesatkan dan pengakuan dusta yang menipu. Demikianlah kita menemukan bahwa akhlaq shiddiq (jujur) merupakan salah satu dasar yang agung dari dasar-dasar bisnis, dimana ia bias memperbaki cacat yang ada, menjauhkan bursa dan pasar modal dari bahaya yang timbul akibat kebohongan, isu-isu tidak bertanggung jawab dan keresahan hati para pelaku bisnis di pasar karena hilagnya kepercayaan diantara mereka. Dari sisi kewajiban bagi perusahaan atau emiten yang mengeluarkan surat-surat berharga untuk bersikap jujur dalam memberikan keterangan dan pernyataan yang diajukan kepada surat-surat kabar, majalah dan lainnya, serta jujur dalam memberikan laporan keuangan serta aktifitas lain perusahaannya. Bagi perusahaan pialang/mediator untuk jujur terhadap para mitra usahanya dalam memberikan informasi yang mereka sampaikan kepada kliennya serta kepada semua pihak yang terkait dengan perdagangan di pasar modal dituntut kejujurannya sehingga terbentuk aktifitas bisnis yang dapat dipercaya.

\section{Tidak Menyembunyikan Informasi}

Kita kadang mendapati diantara para pelaku bisnis ada yang menyampaikan informasi secara jujur atau memberikan keterangan sesuai fakta. Namun diantara mereka ada yang dengan sengaja menyembunyikan dan menutupi sebagian keterangan dan informasi yang penting bagi para investor dan pelaku bursa lainnya. Dia menyembunyikan hal-hal yang bersifat jelas, diketahui dari pasar dan para pelaku yang berinteraksi dengannya. Hal ini merupakan tindakan kriminal yang berbahaya dan tidak kalah kejamnya dari kriminalitas berdusta dan penyesatan.

Islam telah memerintahkan transparansi dan mengharamkan menyembunyikan data bagi penjual dan pembeli serta semua pihak yang bermuamalah dalam bursa efek atau mereka yang tidak bermuamalah namun mereka mempunyai keterangan atau informasi. Rasulullah bersabda: "Tidak halal bagi seorang muslim menjual dari dari saudaranya suatu jual beli dan di dalamnya ada aib, cacat kecuali ia menjelaskannya." (HR. Bukhari).

Penyembunyian dan tidak adanya penjelasan tidak terbatas hanya pada aib/cacat dan kerusakan, tetapi juga mencakup kebaikan-kebaikan dan informasi yang bermanfaat, sehingga wajib bagi setiap orang yang mengetahui berita atau informasi yang bermanfaat dan penting

\section{Created with}


bagi para investor atau semua pelaku bisnis di bursa untuk menyampaikannya kepada khalayak sebagai bagian dari kewajiban menyampaikan nasehat kepada umat Islam.

Hal yang paling berbahaya yang menimpa pasar modal adalah penyembunyian informasi dan keterangan atau menjelaskannya kepada sebagian saja dan menyembunyikan dari yang lain. Pasar dalam Islam dibangun, atas transparansi, penjelasan yang sempurna, dan kesamaan semua pihak yang bermuamalah dalam hak dan kewajiban. Dari sinilah munculnya barakah dalam kejujuran dan penjelasan terhadap sifat dan kondisi komoditi (transparansi) serta hilangnya barakah dari kebohongan dan penyembunyian informasi. (Syahatah Husein dan Athiyyah Fayyadh, 2004:55).

\section{Earnings Management}

Earnings management didefinisikan sebagai disclosure management in the sense of purposeful intervention in the external reporting process, with intent of obtaining some private gain (Shipper, 1989:92). Dari definisi tersebut jelas bahwa earnings management adalah merupakan intervensi langsung manajemen dalam proses pelaporan keuangan dengan maksud mendapat keuntungan atau manfaat tertentu, baik bagi manajer maupun perusahaan.

Dalam perkembangannya, penelitian tentang earnings management telah mencakup berbagai sektor. Salah satunya adalah kemungkinan munculnya earnings management dalam pelaksanaan IPO. Penelitian earnings management di pasar perdana saat IPO antara lain dilakukan oleh (Jones, 1991; Friedlan, 1994; Gumanti, 2001; Setiawati, 2002; Ihalauw dan Afni, 2002), Tiono (2004).

Penelitian tentang earnings management hampir seluruhnya menggunakan pendekatan accruals, sehingga tidak heran ada sebagian penulis yang menyebut earnings management dengan istilah accruals management. Pendekatan yang paling banyak digunakan dalam pengujian earnings management adalah model yang dikembangkan oleh Jones (1991) dan modifikasi model Jones. Pada prinsipnya pendekatan yang digunakan tidak jauh berbeda. Perbedaan penggunaannya biasanya tergantung pada konteks dimana penelitian tersebut dilakukan. Tetapi, secara umum penelitian tentang earnings management menggunakan ukuran berbasis accruals (accruals-based measures) dalam mendeteksi ada tidaknya manipulasi laba.

Salah satu kelebihan dari pendekatan total accruals adalah pendekatan tersebut berpotensi untuk dapat mengungkap cara-cara untuk menurunkan atau menaikkan laba, karena cara-cara tersebut kurang mendapat perhatian untuk diketahui pihak luar. DeAngelo 
(1996:408) menjelaskan bahwa accounting accruals mencerminkan keputusan manajemen, antara lain, untuk menghapuskan asset (write down assets), pengakuan atau penundaan pendapatan (recognition or deferral of revenues), atau menganggap biaya atau modal suatu pengeluaran (capitalize or expense certain costs). Ayres (1994) menambahkan cara-cara lain untuk mempengaruhi tingkat laba, yaitu dengan penerapan suatu kebijakan akuntansi yang wajib (adoption of mandatory accounting changes) baik lebih awal dari tanggal berlakunya atau tepat waktu dan perubahan-perubahan akutansi secara sukarela (voluntary accounting changes).

Dalam Islam terdapat prinsip-prinsip umum akuntansi yang dapat dijadikan acuan dalam penyusunan laporan keuangan (akuntansi) yang terdapat dalam QS. Al-Baqarah: 282, yaitu keadilan, kebenaran, dan pertanggungjawaban. Oleh karenanya nilai keadilan, kebenaran dan pertanggungjawaban pencatatan transaksi dapat berwujud apabila pelaporan akuntansi dilakukan dengan benar, cepat terang jelas, tegas, dan informatif, menyeluruh, ditujukan kepada semua pihak, terperinci dan teliti, tidak terdapat unsur manipulasi, dan dilakukan terus menerus.

Prinsip-prinsip tersebut diatas, dapat diaplikasikan dalam kehidupan di dunia khususnya dalam dunia bisnis, yaitu atas apa yang dilakukan atau apa yang diperbuat oleh seorang (pengusaha) harus dilakukan perhitungan atau pencatatan. Kesemuanya itu akan digunakan sebagai bahan pertangungjawaban. Tujuannya adalah untuk menjaga keadilan dan kebenaran. Artinya prinsip-prinsip tersebut menekankan pada kepentingan pertanggungjawaban agar pihak-pihak yang terlibat dalam transaksi itu tidak dirugikan, tidak timbul konflik, dan adil. Al_Qur'an melindungi kepentingan masyarakat dengan menjaga terciptanya kebenaran dan keadilan. Oleh karena itu tekanan akuntansi Islam bukanlah pada pengambilan keputusan tetapi pertanggungjawaban atau akuntabilitas (accountability) (Muhammad, 2005: 90).

Islam mewajibkan kepada setiap pelaku bisnis muslim untuk amanah, begitu juga mewajibkan kepada para mitra kerjasama antara mereka untuk amanah. Sehingga Islam tidak mengijinkan seorang muslim mengeksploitasi saudaranya sesama muslim ataupun non muslim atau mendzaliminya serta tidak berusaha untuk menipunya.

Dalam QS. Asy-Syuara': 181-183 Allah berfirman: “Sempurnakanlah takaran dan janganlah kamu termasuk orang-orang yang merugikan; dan timbanglah dengan timbangan yang lurus; dan 
jangan kamu merugikan manusia pada hak-haknya dan janganlah kamu merajalela di muka bumi dengan membuat kerusakan."

Dalam hadits sahih dari Rasulullah saw. meriwayatkan dari Tuhannya Allah swt. Berfirman: "Saya (Allah) adalah pihak ketiga dari dua orang yang berserikat (bekerjasama) selama salah satu dari keduanya tidak mengkhianati kawannya, jika mereka berdua berkhianat maka Saya (Allah) keluar dari keduanya".

Dari prinsip-prinsip tersebut diatas tampak bagi kita bentuk-bentuk penipuan, khianat dan penyesatan yang dipraktekkan dalam penyusunan laporan keuangan (akuntansi) tidak diperbolehkan dalam Islam yang akan menyebabkan terjadinya penzaliman dalam praktek bisnis yang dilakukan.

\section{Kinerja Initial Public Offerings (IPO)}

Berdasarkan penelitian yang telah dilakukan di berbagai negara diperoleh hasil bahwa dalam jangka pendek terdapat fenomena underpricing dan dalam jangka panjang terdapat penurunan kinerja (underperformance). Penentuan baik tidaknya kinerja saham, baik jangka pendek maupun jangka panjang dilihat besarnya return abnormal. Apabila return abnormal lebih besar dari nol, menunjukkan kinerja yang outperformed (baik), sebaliknya apabila return abnormal lebih kecil dari nol, menunjukkan kinerja yang underperformance (buruk) (Indarti, 2004). Suatu penjelasan mengenai fenomena underperformance adalah adanya hipotesis asimetri informasi (Senbert dan Guiness, 1992) dalam Rosyati dan Sabeni (2002), informasi asimetris terjadi antara perusahaan emiten dengan underwriter (model Baron) atau antara informend investor dan uninformend investor (model Rock). Model Baron (1982), menjamin emisi dianggap memiliki informasi yang lebih tinggi mengenai permintaan saham perusahaan emiten daripada perusahaan emiten meskipun perusahaan emiten mungkin melakukan earnings management sebelum IPO untuk meningkatkan harga sahamnya (Friedlan, 1994). Underwriter akan memanfaatkan informasi yang dimiliki untuk memperoleh kesepakatan optimal dengan emiten untuk menjual saham yang underpriced. Underwriter melakukan penjualan saham perdana yang underpriced bertujuan untuk memperkecil risiko kemungkinan saham tidak laku dijual serta keharusan membeli saham yang tidak terjual (full commitment). Model ini mengimplementasikan bahwa ketidakpastian yang besar dari perusahaan emiten tentang harga saham, maka permintaan terhadap jasa penjamin semakin besar. 
Model Rock (1986), menjelaskan bahwa informasi asimetris terjadi pada kelompok informed investor dan uninformed investor. Informed investor yang mengetahui informasi lebih banyak mengenai prospek perusahaan emiten akan membeli saham IPO jika after market price yang di harapkan melebihi harga perdana atau dengan kata lain kelompok ini hanya membeli saham IPO yang underpriced saja. Sementara kelompok uniformed investor karena kurang memiliki informasi mengenai perusahaan emiten akan melakukan penawaran secara sembarangan, baik pada saham IPO yang underpriced maupun overpriced. Akibatnya, kelompok uniformed investor memperoleh proporsi yang lebih besar dalam saham IPO yang overpriced daripada kelompok informed investor. Aggarwl, et al. (1993) meneliti mengenai kinerja IPO menunjukkan bahwa pada jangka panjang terjadi return yang negatif.

Beberapa penelitian menghubungkan penurunan kinerja dengan konsep windows of opportunity dan agency theory (Alderson dan Betker, 1997; Trail dan Vos, 2001). Secara konseptual, dalam windows opportunity manajemen berusaha memanfaatkan kesempatan pada saat mengetahui pasar telah menilai perusahaan secara overvalue. Sementara dalam agency theory, manajemen mamanfaatkan asimetri informasi karena kesuperiorannya dalam menguasai informasi dibandingkan pasar. Sehingga dari penjelasan di atas dapat ditarik benang merah bahwa turunnya kinerja perusahaan tersebut berkaitan dengan sikap oportunistik manajemen untuk memanfaatkan kesempatan yang ada, meski dalam jangka panjang manajemen akan kehilangan kendali atas keunggulannya, yang terefleksi dalam penurunan kinerja.

Sejalan dengan penurunan kinerja keuangan, maka penurunan kinerja saham juga akan terjadi sebagai akibat dilakukannya manipulasi pada saat penawaran tersebut (Ritter, 1991; Bowman dan Navissi, 1998). Kondisi tersebut terjadi karena harga saham berkorelasi dengan kinerja keuangan, sehingga penurunan kinerja keuangan akan membuat pasar melakukan koreksi harga saham yang overvalue tersebut.

\section{Penelitian Earnings Managament dalam Konteks IPO}

Penelitian mengenai earnings management dalam konteks IPO telah beberapa kali dilakukan. Penelitian yang menggunakan pasar modal Amerika Serikat sebagai obyek penelitian diantaranya adalah Aharony et al. (1993); Friedlan (1994); Neill, Pourciou, dan Schaever (1995); Magnan and Cournier (1997); Teoh et al. (1998). Neill, Pourciou, dan Schaever menemukan bukti yang kuat atas adanya hubungan antara pemilihan metode akuntansi dan earnings management di IPO. Bila Aharoni et al. tidak menemukan bukti yang kuat adanya 
earnings management, Friedlan, Magnan and Cournier, dan Teoh et al. justru menemukan bukti yang kuat pada periode sebelum IPO pemilik perusahaan melakukan earnings management dengan meningkatkan tingkat keuntungan yang ada. Dari keempat penelitian earnings management di pasar perdana yang ada, terdapat perbedaan dalam pengujian yang digunakan. Aharony et al. dan Friedlan menggunkan pendekatan accruals dengan uji nonparametric, sementara Magnan and Cournier, dan Teoh et al. menggunakan uji regresi berganda sebagaimana dikembangkan oleh Jones (1991).

Penelitian earnings management dengan obyek pasar modal Indonesia antara lain dilakukan oleh Gumanti (2001), Setiawati (2002), Ihalauw dan Afni (2002), Tiono (2004). Penelitian Gumanti (2001) terhadap 39 perusahaan yang go public tahun 1995-1997 menemukan bahwa perusahaan tidak terbukti secara kuat melakukan earnings management pada periode satu tahun sebelum IPO, namun terjadi pada periode dua tahun sebelum IPO. Hal ini disebabkan karena issuers tidak ingin upaya rekayasa laba yang dilakukan diketahui oleh pihak luar dan rekayasa laba sendiri tidak dapat dilakukan terus-menerus.

Hasil penelitian Setiawati (2002) terhadap 24 perusahaan yang go public tahun 1995-2001 membuktikan bahwa terjadi earnings management pada satu periode sebelum dan sesudah IPO. Penelitian Ihalauw dan Afni (2002) terhadap 16 perusahaan yang go public tahun 1998-2000 menemukan bukti bahwa pada periode satu tahun sebelum IPO terjadi earnings management.

Hasil penelitian Tiono (2004) terhadap 81 perusahaan yang melakukan IPO dengan menggunakan pendekatan total accruals menemukan bukti terjadinya earnings management. Dimana, pada periode dua tahun dan satu tahun sebelum IPO, terdapat bukti bahwa issuers melakukan earnings management dengan menerapkan income-increasing discretionary accruals. Sementara itu pada periode satu tahun setelah IPO, pengujian terhadap discretionary accruals menunjukkan hasil yang tidak signifikan.

\section{Penelitian Underpricing dalam Konteks IPO}

Beberapa penelitian mengenai underpricing dalam konteks IPO menunjukkan hasil yang belum konsisten. Penelitian yang dilakukan Husnan (1996) menunjukkan bahwa IPO pada perusahaan-perusahaan yang privat ataupun pada perusahaan milik negara (BUMN) biasanya mengalami underpriced, karena harga pada penawaran perdana lebih rendah daripada harga pada hari pertama perdagangaan di pasar sekunder. Carter dan Manaster (1990) menjelaskan bahwa underpriced adalah hasil dari ketidakpastian harga saham pada pasar sekunder.

\section{Created with}


Selanjutnya penelitian Ernyan dan Husnan (2002) terhadap 133 perusahaan keuangan dan non keuangan yang melakukan penawaran perdana (IPO) selama periode 1991-1997 menunjukkan bahwa penawaran perdana memberikan initial return yang positif dan signifikan untuk semua kelompok perusahaan. Hal ini mengindikasikan bahwa terjadi underpricing pada penawaran perdana (IPO). Tingkat ex-ante uncertainty pada perusahaan keuangan tidak lebih kecil daripada perusahaan non keuangan. Hal ini mengindikasikan bahwa pengawasan terhadap mereka kurang efektif.

Penelitian yang dilakukan Aggarwal, et al. (1993) meneliti mengenai kineja IPO dalam jangka pendek menunjukkan terjadinya underpricing, tetapi dalam jangka panjang menunjukkan terjadinya retrun yang negatif. Sementara penelitian yang dilakukan Allen dan Faulhaber (1989), Grinblatt dan Hwang (1989), serta Welsch (1989) menunjukkan bahwa perusahaan menggunakan underpricing sebagai suatu mekanisme untuk menandai kualitas perusahaan. Hal ini berarti bahwa perusahaan melakukan underpricing saham-saham perdananya akan memberikan kinerja yang lebih baik di masa yang akan datang, dibandingkan dengan perusahaan lain yang tidak melakukan underpricing.

Penelitian yang dilakukan Beatty (1989), serta Ritter (1986 ), underpriced disebabkan oleh adanya asimetri informasi. Studi yang memfokuskan tentang asimetri informasi antara pemilik dengan investor dilakukan oleh Leland dan Pyle (1997) pemilik lama dan manajemen merupakan pihak yang memiliki informasi secara lengkap. Kunz dan Aggarwal (1994), membahas enam variabel yang berpengaruh terhadap underpriced yaitu market, number, standar deviasi, underwriter dan hukum. Ronald, et al. (1988), yang menginformasikan bahwa auditor dan investor banker reputation mempengaruhi besarnya underpricing.

Penelitian yang dilakukan Bon, et al. (1993) meneliti sampel yang mengambil 177 perusahaan yang melakukan IPO di KSE perioda 1988-1990 penelitian ini menguji tingkat underpricing dalam penawaran saham perdana. Hasilnya menunjukkan ada perbedaan sistematis dalam kinerja saham perdana dari saham baru yang dikeluarkan bila ada perbedaan tujuan motif dari mempublik. Tingkat underpricing secara signifikan lebih tinggi bila perusahaan memandang mempublik sebagai sumber terakhir pendanaan, daripada keinginan pemegang saham untuk mendeversifikasikan kepemilikan mereka.

\section{Penelitian Kinerja Perusahaan dalam Konteks IPO}


Pratiwi dan Kusuma (2001) meneliti tentang kinerja surat berharga setelah IPO di Indonesia tahun 1994-1997, hasilnya menunjukkan bahwa kinerja IPO jangka pendek (tiga bulan) adalah positif $(39,67 \%)$ dan kinerja jangka panjang (dua puluh empat bulan) adalah negatif $(-238,83 \%)$. Bukti ini menunjukkan bahwa dalam jangka panjang telah terjadi penurunan kinerja (underperformance).

Hasil penelitian Nasirwan (2002) menunjukkan bahwa kinerja perusahaan dalam jangka panjang mengalami penurunan, penurunannya relatif kurang tajam untuk saham perusahaan yang dikelola oleh underwriter yang mempunyai reputasi tinggi. Kecenderungan menurunnya kinerja perusahaan satu tahun sesudah IPO tampak dari nilai mean dan median-nya. Hasil ini juga memperoleh dukungan dari Carter (1998) bahwa kinerja saham dalam jangka panjang cenderung menurun.

Penelitian Bowman dan Navissi (1998) menghubungkan penurunan kinerja dengan earning management, penurunan kinerja saham terjadi sebagai akibat dilakukannya manipulasi pada saat penawaran tersebut. Kondisi tersebut terjadi karena harga saham berkorelasi dengan kinerja keuangan, sehingga penurunan kinerja keuangan akan membuat pasar melakukan koreksi harga saham yang overvalue tersebut.

Hasil penelitian Rodoni (2002) menyimpulkan keuntungan rata-rata setelah dipasarkan untuk jangka pendek, apakah keuntungan harian berdasarkan harga penutup, keuntungan berdasarkan harga pembukaan dan keuntungan berdasarkan harga pembukan terhadap harga penutup untuk tempo masa studi menunjukkan bahwa perdagangan pasaran pada peringkat kedua adalah tidak menguntugkan. Keadaan ini didukung oleh hasil penelitian Jennings (1993) dan Yong (1997). Penemuan ini juga menunjukkan keuntungan yang rendah pada pelanggan permulaan dan disesuaikan pada kesan pasaran dalam satu hari setelah penawaran dilaksanakan adalah tidak signifikan. Penelitian ini juga menemukan kinerja IPO untuk jangka panjang menunjukkan kinerja yang kurang baik atau kurang menguntungkan, seperti temuan Ritter (1991), Agrawal et al. (1993), Levis (1993), Fauzias et al. (1996) dan Teoh et al. (1996).

\section{KESIMPULAN}

Perusahaan yang akan go public biasanya dimulai dengan keputusan melakukan initial public offerings (IPO) yang dilakukan di pasar perdana (primary market). Selanjutnya saham tersebut akan di perjual-belikan di pasar modal atau disebut pasar sekunder (secondary market). 
Salah satu hal yang tidak diinginkan oleh pihak emiten adalah terjadi underpricing yang terlalu tinggi, yaitu keadaan dimana harga saham hari pertama di pasar sekunder (bursa) lebih besar dari pada harga saham perdananya. Underpricing merupakan fenomena yang menarik karena dialami oleh sebagian besar pasar modal di dunia. Fenomena lain menunjukkan adanya asimetri informasi (asymmetric information) yang menyertai kebijakan IPO. Walaupun investor mempunyai informasi yang cukup mengenai perusahaan yang melakukan IPO tersebut, asimetri informasi tetap terjadi dalam penawaran ini. Kondisi inilah yang memotivasi manajemen untuk bersikap oportunistik untuk melakukan manipulasi terhadap kinerjanya baik sebelum dan pada saat penawaran. Manipulasi yang dikenal dengan istilah earnings management (manajemen laba) ini akan mengakibatkan penurunan kinerja (underperformance) setelah penawaran. Namun praktek earnings management di sisi lain dapat mempengaruhi nilai perusahaan. Kondisi ini terjadi karena earnings yang diumumkan pada saat IPO tampak relatif baik sehingga respon pasar menjadi positif. Kebijakan earnings management dalam hal ini ditujukan untuk memberikan sinyal positif kepada pasar tentang perusahaan yang dikelolanya. Sinyal positif ini diwujudkan dalam kinerja yang dilaporkan (biasanya dalam prospektus penawaran). Namun sinyal positif ini dalam jangka panjang tidak bisa dipertahankan oleh manajemen, yang tercermin dari penurunan kinerja yang dilaporkan oleh perusahaan tersebut.

Syari'at Islam menyikapi fenomena yang terjadi diseputar IPO dengan sikap yang jelas dan tegas. Islam tidak mengijinkan sama sekali segala bentuk penyimpangan dengan alasan apapun. Terdapat prinsip-prinsip umum yang harus diikuti terutama dalam praktek pembuatan laporan keuangan (akuntansi), yaitu keadilan, kebenaran, dan pertanggungjawaban. Oleh karenanya nilai keadilan, kebenaran dan pertanggungjawaban pencatatan transaksi dapat terwujud apabila pelaporan akuntansi dilakukan dengan benar, cepat, terang, jelas, tegas dan informatif, menyeluruh ditujukan kepada semua pihak, terperinci dan teliti, tidak terdapat unsure manipulasi dan dilakukan secara terus menerus. Islam telah memerintahkan transparansi dan mengharamkan menyembunyikan data bagi semua pihak yang bermuamalah dalam bursa efek atau mereka yang tidak bermuamalah namun mereka mempunyai keterangan atau informasi, sehingga tidak terjadi asymmetric information. Al-Qur'an melindungi kepentingan masyarakat dengan menjaga terciptanya kebenaran dan keadilan sehingga tidak terdapat pihak-pihak yang dirugikan dalam bertransaksi dan tidak menimbulkan konflik. 


\section{DAFTAR PUSTAKA}

Aharony, Joseph, Chan-Jane Lin, dan Martin P. Loeb. 1993. Initial Public Offerings, Accounting Choices, and Earnings Management. Contemporary Accounting Research. Vol 10. No 1. hal.61-68

Beneish, Messod D. 2001. Earnings Management: A Prespective. Managerial Finance. Vol 27. No 12. hal.3-17

Carter, R.B., F.H. Dark., dan A.K. Singh. 1998. Underwriter Reputation, Initial Returns, and the Long-run Performance of IPO Stocks. The Journal of Finance. Vol LIII. No 1(Pebruari). hal.285-311

DeAngelo, Linda E. 1986. Accounting Numbers as Market Valuation Subtitutes: A Study of Management Buyouts of Public Stockholders. The Accounting Review. Vol 59. hal.400-420

Friedlan, John M. 1994. Accounting Choices of issuers of Initial Public Offerings. Contemporary Accounting Research.Vol 11. Summer 1994. hal.1-31

Gumanti, Tatang Ari. 2002. Earnings Management dalam Penawaran Saham Perdana di Bursa Efek Jakarta. Kumpulan Makalah SNA V. hal.124-148

2003. Motivasi di Balik Earnings Management. Usahawan. No 12. Th. XXXII. Desember 2003. hal.21-26

Healy, P.M. dan James M. Wahlen. 1999. Commentary: A Review of The Earnings Management Literature and Its Implications for Standard Setting. Accounting Horizons. Vol 13. No 4. hal.365-383

Muhammad. 2005. Pengantar Akuntansi Syari'ah, Edisi 2. Jakarta: Penerbit Salemba Empat.

Nasirwan, 2002. Reputasi Penjamin Emisi, Return Awal, Return 15 Hari Sesudah IPO, dan Kinerja Perusahan Satu Tahun Sesudah IPO di BEJ. Kumpulan Makalah SNA V. hal.573598.

Ritter, Jay R. 1991. The Long-run, Performance of Initian Public Offerings. Journal of Finance. Vol 46. hal.3-27

Syahatah, Husein dan Athiyyah Fayyadh. 2004. Bursa Efek, Tuntunan Islam dalam Transaksi di Pasar Modal. Surabaya: Penerbit Pustaka Progressif.

Tiono, Fransiska. 2004. Manajemen Laba dalam Initial Public Offerings (IPO) di Bursa Efek Jakarta. Kumpulan Makalah SNA VII. hal.1072-1089 